\title{
KONSEP MULTIPLE INTELLIGENCES PERSPEKTIF AL-QURAN/ HADIS DAN IMPLIKASINYA TERHADAP PEMBELAJARAN PENDIDIKAN AGAMA ISLAM
}

\author{
Hofur \\ Universitas Islam Negeri Sunan Kalijaga Yogyakarta \\ Hofurpai19@gmail.com
}

\begin{abstract}
ABSTRAK
Penelitian ini bertujuan untuk mengetahui perpsektif al Quran/ Hadis tentang multiple intelligences dan implikasinya terhadap pembelajaran Pendidikan Agama Islam. Penelitian ini merupakan penelitian library research. Melalui kunjungan perpustakaan data yang diambil berasal dari buku, seperti: Tafsir Al-Misbah, Tafsir Ath-Thabari, Tafsir Thabrani, Tafsir Ibnu Katsir, Kitab Hadis AIMustadrak dan sumber lainnya yang memiliki keterkaitan dengan tema penelitian. Sumber data penelitian ini dibagi ke dalam sumber data primer dan sumber data sekunder. Hasil penelitian ini menunjukan: (1) konsep multiple intelligences perspektif al Quran/ Hadis dapat dijumpai masing-masing, kecerdasan linguistik dalam Q.S. AlBaqarah: 31-33; kecerdasan logis matematis dalam Q.S. Al Ankabut:43; kecerdasan visual-spasial dalam Q.S. Hud: 37-38; kecerdasan kinestetik dalam Q.S. Al-Maidah: 31; kecerdasan kecerdasan irama-musik dalamhadis riwayat Hakim No. 2125 kitab al-Mustadrak; kecerdasan interpersonaldalam Q.S. Al-Hujarat: 13; kecerdasan intrapersonal dalam Q.S. Ad-Dzariyat: 21;kecerdasan naturalis dalam Q.S. Ali Imran: 190-191; kecerdasan eksistensial dalam Q.S. Ad-Dzariyat: 56. (2) Implikasi multiple intelligences terhadap pembelajaran PAI, Multiple Intelligences sangat diperlukan dalam model pembelajaran dewasa ini. Guru sangat dimudahkan apabila mampu melihatkecerdasan yang dimiliki setiap siswa. Materi disampaikan dengan strategi pembelajaran yang dapat memfasilitasi setiap kecerdasan yang dilmiliki siswa. Melalui strategi tersebut siswa memiliki motivasi tinggi dikarenakan proses pembelajaran lebih variatif. Poin penting disini adanya pengakuan baik secara langsung maupun tidak langsung terhadap kemampuan yang dimiliki siswa tanpa pengecualian.
\end{abstract}

Kata Kunci: Multiple Intelligences, Al Quran/ Hadis, PAI

\section{ABSTRACT}

This study aims to determine the perspective of the Quran/ Hadith about multiple intelligences and its implications for learning Islamic Religious 
Education. This research is a research library research. Through library visits, data is taken from books, such as Tafsir Al-Misbah, Tafsir Ath-Tabari, Tafsir Thabrani, Tafsir Ibn Katsir, Al Mustadrak Hadith Book, and other sources related to the research theme. The data sources of this research are divided into primary data sources and secondary data sources. The results of this study indicate: (1) the concept of multiple intelligences in the perspective of the Quran / Hadith can be found, respectively, linguistic intelligence in Q.S. Al-Baqarah: 31-33; mathematical logical intelligence in Q.S. Al Ankabut: 43; visual-spatial intelligence in Q.S. Hud: 37-38; kinesthetic intelligence in Q.S. Al-Maidah: 31; rhythm-music intelligence in the Hadith history of Judge No. 2125 Kitab al-Mustadrak; interpersonal intelligence in Q.S. Al-Hujurat: 13; intrapersonal intelligence in Q.S. AdDzariyat: 21; naturalist intelligence in Q.S. Ali Imran: 190-191; existential intelligence in Q.S. Ad-Dzariyat: 56. (2) The implications of multiple intelligences for PAl learning, Multiple Intelligences are needed in today's learning models. Teachers are very facilitated if they can see the intelligence possessed by each student. The material is presented with learning strategies that can facilitate each student's intelligence. Through this strategy, students have high motivation because the learning process is more varied. The important point here is the recognition, either directly or indirectly, of the abilities possessed by students without exception.

Keywords: Multiple Intelligences, Al Quran/ Hadis, PAI.

\section{PENDAHULUAN}

Semua anak pada dasarnya adalah cerdas. Melalui kecerdasan yang dimilikinya setiap anak mampu mengeksplorasi dunianya dan memecahkan masalah yang dihadapinya. Berbagai kecerdasan yang dimiliki oleh masing-masing anak ini dapat menjadi modalitas dalam belajar.(Yuliani Nurani and Bambang, 2010, p. 8). Pada umumnya orang berpendapat bahwa intelegensi merupakan bekal potensial yang akan memudahkan dalam belajar dan pada gilirannya akan menghasilkan performansi yang optimal.(Azwar, 1996, p. 163)

Pendidikan Agama Islam merupakan usaha sadar yang dilakukan pendidik dalam rangka mempersiapkan peserta didik untuk meyakini, memahami, dan mengamalkan ajaran Islam melalui kegiatan bimbingan, pengajaran atau pelatihan yang telah ditentukan untuk mencapai tujuan yang telah ditetapkan.(Majid and Andayani, 2004, p. 132). Tujuan Pendidikan Agama Islam adalah terbentuknya peserta didik yang beriman dan bertakwa kepada Allah SWT, berbudi pekerti luhur (akhlak mulia), memiliki pengetahuan tentang ajaran pokok agama Islam dan mengamalkan dalam kehidupan sehari-hari, serta memiliki pengetahuan yang luas 
dan mendalam tentang Islam, sehingga memadai baik untuk kehidupan bermasyarakat maupun untuk melanjutkan pendidikan ke jenjang yang lebih tinggi.(2004, pp. 2-3)

Mengingat betapa pentingnya tujuan Pendidikan Agama Islam maka dalam pembelajaran harus disusun sedemikian rupa model pembelajaran yang mampu mengakomodasi beragam kecerdasan yang dimiliki siswa. Pendidik harus membuat pembelajaran dengan beragam kreasi sehingga siswa akan merasa tertarik sehingga kecerdasan yang dimiliki dapat berkembang dengan optimal. Apabila kecerdasan majemuk dapat dioptimalkan dengan baik, maka akan berdampak pada hasil belajar siswa dan tujuan pembelajaran tersebut.

Multiple intelligences merupakan teori kecerdasan yang dikemukakan oleh Howard Gardner, seorang psikolog dari Harvard University, bahwa setiap anak punya kecenderungan kecerdasan dari sembilan kecerdasan, yaitu cerdas bahasa (linguistik), cerdas matematis logis (kognitif), cerdas gambar dan ruang (visualspasial), cerdas musik, cerdas gerak (kinestetis), cerdas bergaul (interpersonal), cerdas diri (intrapersonal), cerdas alam, dan cerdas eksistensi.(Chatib, 2016, pp. 7778)

Multiple Intelligences sangat diperlukan dalam model pembelajaran dewasa ini. Guru sangat dimudahkan apabila mampu melihat kecerdasan yang dimiliki setiap siswa. Diungkapkan oleh Eman Relvan bahwa ada beberapa implikasi multiple intelligences dalam pembelajaran PAI, diantaranya (1) Rumusan tujuan lebih mengarah pada mendorong siswa belajar secara optimal sehingga potensi (fitrah) dapat terarahkan pada kesempurnaan. (2) Dengan mengetahui lebih dari satu kecerdasan memunculkan metode belajar yang kreatif, yaitu dengan menggunakan masing-masing kecerdasan sebagai metode belajar (3) materi pelajaran harus berisi sekumpulan kemampuan yang berorientasi pada perilaku afektif dan psikomotorik dengan dukungan pengetahuan kognitif dalam rangka memperkuat keimanan dan ketaqwaan terhadap Allah SWT (4) Evaluasi berupa penilaian yang dapat menguji pemahaman siswa tentang materi pelajaran secara lebih menyeluruh dan kontinu.(Relvan, 2005)

Pendidikan di Indonesia bisa dikatakan hanya mengukur dua atau tiga jenis kecerdasan dengan mengabaikan jenis kecerdasan lainnya. Ketika ujian akhir sekolah selesai dan kenaikan kelas menjelang, sekolah membanggakan diri dengan kegiatan yudisium. Yudisium telah menjadi legitimasi aneka penghargaan kepada anak-anak 
didik yang unggul dalam pelajaran matematika, ilmu pengetahuan alam, dan ilmu kebahasaan-misalnya bahasa Inggris. Sementara anak didik yang hebat di bidang seni atau anak didik yang mewakili sekolah dalam kejuaraan futsal tidak diapresiasi sebagai juara kelas.(Chatib and Said, 2012, p. 15)

Konsep kecerdasan jamak (multiple intelligences) belum terintegrasi secara optimal dalam setiap penyelenggaraan pendidikan di sekolah padahal hal tersebut merupakan bagian yang tak terpisahkan dalam pengelolaan pendidikan di negaranegara maju. Padahal model pembelajaran yang perlu dikembangkan dalam sekolah modern adalah model pembelajaran demokratis. Artinya proses pendidikan harus diarahkan pada kegiatan untuk melatih, mengelola pembelajaran, berpartisipasi, memimpin, membelajarkan, dan mengarahkan siswa tanpa ada perbedaan suku, ras, agama, bahasa,status sosial, gender, kemampuan, dan letak geografis.(Yaumi and Ibrahim, 2013, p. 5)

Kecerdasan jamak seringkali justru dapat membantu para pendidik termasuk orang tua untuk mengenali kelebihan dalam diri seorang anak. Walaupun demikian para pendidik jangan cepat-cepat mengambil kesimpulan tentang kecenderungan kecerdasan yang dimiliki oleh anak, tanpa memberikan kesempatan pada anak untuk bereksplorasi bekerja dengan keterampilan sendiri dan mengembangkan kemampuan mereka sendiri.(Yuliani Nurani and Bambang, 2010, p. 9)

Kenyataan tersebut menunjukan betapa pentingnya pemahaman guru terhadap kecerdasan yang dimiliki setiap anak. Lebih-lebih bagi calon dan guru PAI yang masih dianggap oleh masyarakat masih menggunakan model pembelajaran yang konservatif. Hal tersebut harus menjadi motivasi ketika mengajarkan materi agama Islam hendaknya menggunakan model pembelajaran yang bervariasi dengan menyesuaikan kecerdasan masing-masing anak. Lebih dari itu guru harus berperan sebagai fasilitator siswa dalam mengembangkan berbagai kecerdasannya.

Al Quran sebagai pedoman umat Islam menunjukan bahwa manusia diciptakan dengan bermacam-macam karakter dengan kelebihan dan kekurangannya masing-masing. Al Quran sebagai kitab suci umat Islam di dalamnya memuat berbagai informasi dan ilmu pengetahuan. Salah satunya berkaitan dengan kecerdasan manusia. Begitu juga dengan hadis yang merupakan sumber hukum Islam kedua setelah al Quran selalu memberikan penjelasan atas hal-hal yang masih universal. 
Guru PAI sebagai orang yang mengajarkan agama Islam harus mempunyai landasan dalam melihat kecerdasan anak didiknya terutama yang bersumber dari al Quran/ Hadis. Kenyataan di lapangan masih banyak guru terutama guru PAI masih mengambil landasan berfikirnya terhadap pemikiran Barat. Tentunya sebagai orang Islam harus mengambil landasan tersebut yang berasal dari al Quran/ Hadis.

\section{METODE PENELITIAN}

Dalam penelitian menggunakan jenis penelitian kepustakaan (library research). Kepustakaan adalah salah satu jenis penelitian yang dilakukan oleh peneliti dengan mengumpulkan data-data yang bersumber dari buku, jurnal, artikel dan tulisan-tulisan tertentu. Dalam konteks ini digunakan sumber data primer yakni yang bersumber dari buku tentang multiple intelligences, kitab tafsir dan kitab hadis. Sedangkan data penunjang dalam penelitian ini adalah data-data yang bersumber dari jurnal, artikel internet yang memiliki keterkaitan erat dengan tema penelitian. Penulis menggunakan pendekatan deskriptif-analitis, yakni setelah data terkumpul, maka diklarifikasikan sesuai dengan masalah yang dibahas dan dianalisis isinya (content analysis), dibandingkan antara data yang satu dengan lainnya, kemudian diintrepetasikan dan akhirnya disimpulkan.

\section{PEMBAHASAN}

\section{A. Multiple Intelligences Perspektif Al Quran/ Hadis}

Pengetahuan tiap manusia di awal kehidupannya adalah sama, semua bermula dari nol. Dengan alat indera yang ada padanya sebagai anugerah Allah SWT kemudian manusia sedikit demi sedikit menyerap informasi dan disimpan di dalam memorinya sebagai pengetahuan siap untuk digunakan dalam kehidupannya dan atau dihubung-hubungkan dengan pengetahuan lain yang mampu melahirkan berbagai bentuk kreasi masing-masing.(Lajnah Pentashihan Mushaf Al-Qur'an, 2010, p. 340) Berkenaan dengan hal ini Allah berfirman sebagaimana dapat dibaca dalam Surah an-Nahl ayat 78 berikut ini:

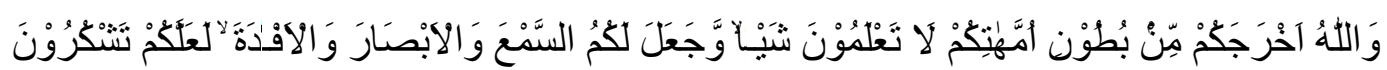

Artinya: Dan Allah mengeluarkan kamu dari perut ibumu dalam keadaan tidak mengetahui sesuatu pun, dan Dia memberimu pendengaran, penglihatan, dan hati nurani, agar kamu bersyukur.(Kementerian Agama, 2014, p. 275) 
Menurut Abu Muhammad Makki al-Qairuwani ketika menafsirkan ayat diatas bahwa Allah mengajari manusia sesuatu yang belum diketahuinya ketika masih di dalam rahim ibunya, melalui anugerah akal (kecerdasan) memahami berbagai hal, membedakan antara yang baik dan buruk, serta mendengarkan ajaran-ajaran Allah SWT. Huruf wawu dalam ayat itu tidak mengindikasikan urutan-urutan penciptaan, karena pendengaran, penglihatan, dan pemahaman terjadi secara simultan. Akan tetapi, seperti dikemukakan oleh asy-Sya'rawi, penyebutan pendengaran terlebih dahulu baru kemudian penglihatan dan pemahaman, karena dalam kenyataannya memang demikian urutan 'aktivitasnya'. Urut-urutan kata dalam ayat menunjukan urutan alamiah (at-tartib at-tabi'i).

Sesuai dengan hasil penelitian, di awal kehidupan manusia, segera setelah persalinan, indera pendengaranlah yang paling pertama berfungsi, kemudian setelah sekitar sepuluh hari barulah menyusul penglihatan. Dari hasil penginderaan diperoleh informasi (pengetahuan) yang tersusun dalam memori yang dikenal dengan pemahaman. Sementara pakar yang lain berpendapat bahwa indera penglihatanlah yang dahulu aktif dibandingkan dengan indera-indera yang lain. Yang mana pun di antara keduanya lebih dahulu, yang jelas bahwa kedua indera itu yang menjadi penyumbang terbesar dalam proses transformasi ilmu pengetahuan. Mata dan telinga mempunyai andil paling besar dalam mengantarkan informasi ke dalam memori manusia menjadi serangkaian pengetahuan.(Lajnah Pentashihan Mushaf Al-Qur'an, 2010, p. 341)

Dari sensasi (penginderaan), persepsi, dan berpikir manusia memiliki pengalaman dan pengetahuan yang digunakan untuk mengambil keputusan, mewujudkan kreativitasnya, dan mengatasi persoalan yang dihadapi dalam kehidupannya. Tak dapat dipungkiri bahwa potensi itu sudah dibawa sejak lahir. Adanya jaringan otak di dalam kepala, berbagai instrumen indera, dan seluruh perangkatnya telah diciptakan Allah SWT sejak di dalam rahim ibu meskipun belum fungsional saat itu. Jaringan otak adalah instrumen yang paling dominan dalam pembentukan kecerdasan.(Lajnah Pentashihan Mushaf Al-Qur'an, 2010, p. 342)

Setiap orang memiliki tingkat dan bidang kecerdasan yang berbeda-beda. Hal ini penting sebab dengan begitu manusia memiliki spektrum keahlian yang berbedabeda pula. Dengan perbedaan itu maka manusia melakukan aktivitas juga berbedabeda. Tiap orang melakukan aktivitas menurut kemampuan, keahlian, cara pandang, 
dan kepribadiannya.(Lajnah Pentashihan Mushaf Al-Qur'an, 2010, p. 346) Firman Allah SWT dalam surah al-Isra' ayat 84.

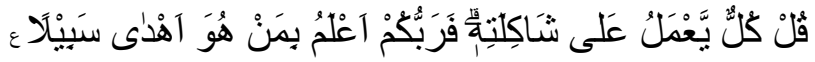

Artinya: Katakanlah (Muhammad), "Setiap orang berbuat sesuai dengan pembawaannya masing-masing." Maka Tuhanmu lebih mengetahui siapa yang lebih benar jalannya.(Kementerian Agama, 2014, p. 290)

Ungkapan 'ala syakilatih' mengacu pada kemampuan, kondisi, kepribadian, kecenderungan, karakteristik, cara dan sudut pandang yang boleh jadi berbeda-beda pada tiap individu. Menurut Abu Su'ud setiap orang berbuat menurut cara yang membawa dia kepada petunjuk atau kesesatan, atau menurut substansi rohnya dan potensi-potensi bawaan yang menyertai fisiknya. Hal lain yang juga berpengaruh pada sikap dan tingkah laku manusia adalah tingkat dan jenis kecerdasan yang dimilikinya. Tingkat dan jenis kecerdasan manusia bersifat terberi (gifted), yaitu bersumber dari Yang Maha Agung. Allah SWT menciptakan manusia dan memberinya bentuk sesuai dengan kehendak-Nya.(Lajnah Pentashihan Mushaf Al-Qur'an, 2010, p. 346)

Penciptaan manusia secara utuh (jasad dan ruh) termasuk pula di dalamnya potensi kecerdasan masing-masing yang siap dikembangkan dan diaktualisasikan. Saat ini para ahli di bidang psikologi meyakini adanya beberapa kecerdasan yang dimiliki oleh manusia. Bukan hanya kecerdasan intelektual tetapi juga kecerdasankecerdasan lain seperti kecerdasan spiritual, natural dsb. Howard Gardner dan ahli yang lain menemukan beberapa kecerdasan yang mungkin dimiliki manusia, lazim disebut sebagai multiple intelligences (kecerdasan jamak). Berikut ini penjabaran masing-masing kecerdasan

\section{Kecerdasan Bahasa}

Diantara nikmat terbesar yang diperoleh manusia dan yang membedakannya dari hewan adalah kemampuannya untuk belajar bahasa. Bahasa adalah sarana terpenting bagi manusia untuk berpikir, memperoleh pengertian, dan ilmu pengetahuan. Bahasa memungkinkan manusia untuk memahami semua pengertian dalam pemikirannya dengan cara simbolis.(Najati, 2010, p. 140) Quraish Shihab dalam bukunya Wawasan Al Quran menyebutkan bahwa manusia adalah makhluk yang berkemampuan untuk menyusuan konsepkonsep, mencipta, mengembangkan, dan mengemukakan gagasan, serta melaksanankannya (Shihab, 1996, pp. 282-283). 
Karena bahasa merupakan hal yang sangat penting dalam kehidupan manusia yang memungkinkannya untuk mencapai kemajuan yang terus menerus dalam belajar dan pemikirannya maka hal yang pertama-tama diajarkan Allah kepada Adam nama-nama segala sesuatu.(Najati, 2010, pp. 170-171) Kecerdasan linguistik yang merupakan kemampuan berbahasa yang terkandung dalam diri Adam, sebagai manusia berakal pertama, menurut al Quran, Adam dilebihkan atas makhluk Tuhan yang lain, sehingga iblis harus tunduk padanya karena Adam memiliki kemampuan untuk menyebut nama-nama, suatu keahlian menciptakan, dan memahami simbol-simbol (Pasiak, 2002, p. 196).

Kecerdasan lingusitik mewujudkan dirinya dalam kata-kata, baik dalam tulisan maupun lisan. Orang yang memiliki jenis kecerdasan ini juga memiliki keterampilan auditori (berkaitan dengan pendengaran) yang sangat tinggi, dan mereka belajar melalui mendengar. Mereka gemar membaca, menulis dan berbicara, dan suka bercengkrama dengan kata-kata.(Jasmine, 2012, p. 17) Firman Allah Surat Al-Baqarah ayat 31-33:

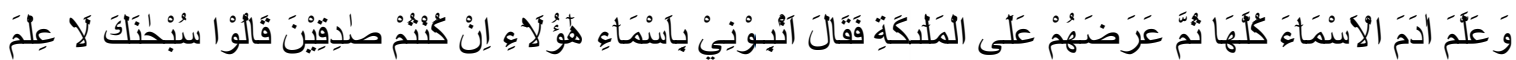

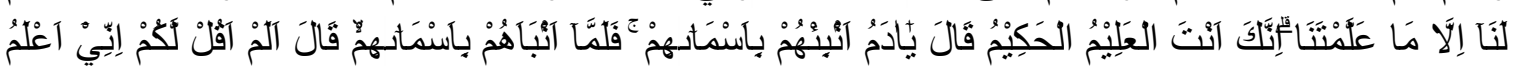

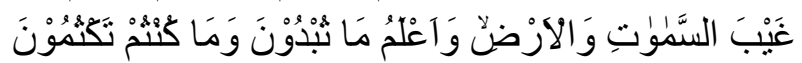

Artinya : Dan Dia ajarkan kepada Adam nama-nama (benda) semuanya, kemudian Dia perlihatkan kepada para malaikat, seraya berfirman, "Sebutkan kepada-Ku nama semua (benda) ini, jika kamu yang benar!" Mereka menjawab, "Mahasuci Engkau, tidak ada yang kami ketahui selain apa yang telah Engkau ajarkan kepada kami. Sungguh, Engkaulah Yang Maha Mengetahui, Mahabijaksana.” Dia (Allah) berfirman, “Wahai Adam! Beritahukanlah kepada mereka nama-nama itu!" Setelah dia (Adam) menyebutkan nama-namanya, Dia berfirman, "Bukankah telah Aku katakan kepadamu, bahwa Aku mengetahui rahasia langit dan bumi, dan Aku mengetahui apa yang kamu nyatakan dan apa yang kamu sembunyikan?"(Kementerian Agama, 2014, p. 6).

Ayat ini menginformasikan bahwa manusia dianugerahi Allah potensi untuk mengetahui nama atau fungsi dan karakteristik benda-benda, misalnya fungsi api, fungsi angin, dan sebagainya. Dia juga dianugerahi potensi untuk berbahasa.(Shihab, 2005a, p. 145) Ini adalah maqam dimana Allah menceritakan 
Adam dan memuliakannya atas malaikat karena Dia mengajarinya sesuatu yang tidak diajarkan kepada malaikat.

Proses belajar yang dilalui Adam juga dilalui oleh semua keturunannya. Sejak kecil, manusia mengamati bahwa sebagian mempunyai kesamaan dan perbedaan dalam beberapa karakteristiknya. Manusia tidak akan bisa memahami semua benda yang ada di sekelilingnya dan tidak bisa memberikan respon karena masing-masing benda berdiri sendiri. Bahkan ia cenderung untuk menyederhanakan proses pengamatannya dengan cara mengelompokan berdasarkan persamaan-persamaannya, membuat pengertian, menamai, dan memberi respon terhadapnya. Demikianlah manusia mengklasifikasikan segala sesuatu untuk mengurangi jumlahnya yang begitu banyak dan beragam dengan menyederhanakan melalui rumusan konsep dan memberinya nama yang melambangkan konsep tersebut. Kemampuan seseorang untuk belajar bahasa akan membantunya dalam merumuskan konsep-konsep dengan cepat, lalu mempergunakannya dalam proses berpikir dan mempelajari informasi-informasi baru.(Najati, 2010, p. 142)

\section{Kecerdasan Logis-Matematis}

Kecerdasan logis-matematis berhubungan dengan dan mencakup kemampuan ilmiah.(Jasmine, 2012, p. 19) Termasuk dalam inteligensi tersebut adalah kepekaan pada pola logika, abstraksi, kategorisasi, dan perhitungan. Pemikiran orang berinteligensi logis-matematis adalah induktif dan deduktif. Jalan pikirannya bernalar dan dengan mudah mengembangkan pola sebab akibat. Bila menghadapi persoalan, ia akan menganalisisnya secara sistematis, baru kemudian mengambil langkah untuk memecahkannya.(Suparno, 2004, p. 29) Allah mengisyaratkan kemampuan orang yang memiliki kecerdasan logis-matematis dalam surah Al-Ankabut ayat 43.

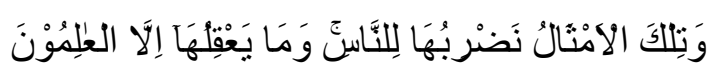

Artinya; Dan perumpamaan-perumpamaan ini Kami buat untuk manusia; dan tidak ada yang akan memahaminya kecuali mereka yang berilmu.(Kementerian Agama, 2014, p. 401)

Firman-Nya yang berbicara tentang amtsal al-Qur'an sebagai: "Tiada ada yang memahaminya kecuali orang-orang alim" mengisyaratkan bahwa perumpamaan-perumpamaan dalam al-Qur'an mempunyai makna-makna yang 
dalam, bukan terbatas pada pengertian kata-katanya. Masing-masing orang sesuai kemampuan ilmiahnya dapat menimba dari matsal itu pemahaman yang boleh jadi berbeda, bahkan lebih dalam dari orang lain. Ini juga berarti bahwa perumpamaan yang dipaparkan di sini bukan sekedar perumpamaan yang bertujuan sebagai hiasan kata-kata tetapi ia mengandung makna serta pembuktian yang sangat jelas (Shihab, 2006, p. 502).

Perumpamaan ini dan sebangsanya, yang terkandung dalam Al-Kitab Al'Aziz dibuat bagi manusia untuk mendekatkan pemahaman mereka kepada apa yang sulit untuk mereka pahami, dan untuk memperjelas apa yang perkaranya terasa sulit oleh mereka, hikmahnya sulit digali, intisarinya sulit dipahami dan pengaruhnya sulit diketahui serta sulit diikuti, karena fadahnya yang terlalu banyak, kecuali oleh orang-orang yang ilmunya mendalam dan yang berpikir tentang akibat segala perkara (Al-Maragi, 1986, p. 250).

Salah satu indikator orang yang memiliki kecerdasan logis-matematis adalah kemampuannya melihat fenomena alam dengan kacamata matematika. Seperti tertulis dalam surah Yunus ayat 5 berikut.

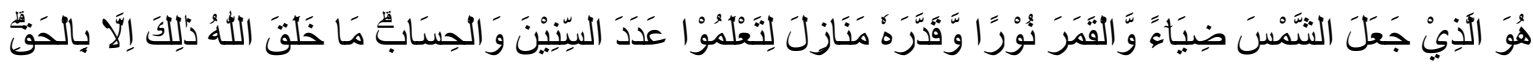

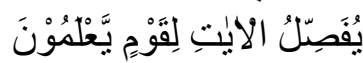
Artinya; Dialah yang menjadikan matahari bersinar dan bulan bercahaya, dan Dialah yang menetapkan tempat-tempat orbitnya, agar kamu mengetahui bilangan tahun, dan perhitungan (waktu). Allah tidak menciptakan demikian itu melainkan dengan benar. Dia menjelaskan tandatanda (kebesaran-Nya) kepada orang-orang yang mengetahui.(Kementerian Agama, 2014, p. 208)

Kata qaddarahu manazila dipahami dalam arti Allah SWT menjadikan bagi bulan manzilah-manzilah, yakni tempat-tempat dalam perjalanannya mengitari matahari, setiap malam ada tempatnya dari saat ke saat sehingga terlihat di bumi ia selalu berbeda sesuai dengan posisinya dengan matahari. Inilah yang menghasilkan perbedaan-perbedaan bentuk bulan dalam pandangan dari bumi. Dari sini pula dimungkinkan untuk menentukan bulan-bulan Qamariyah. Untuk mengelilingi bumi, bulan menempuhnya selama 29 hari 12 jam 44 menit dan 2,8 detik.(Shihab, 2002a, pp. 333-334)

\section{Kecerdasan Visual-Spasial}


Kecerdasan spasial, yang kadang-kadang disebut kecerdasan visualspasial, adalah kemampuan untuk membentuk dan menggunakan model mental. Orang yang memiliki kecerdasan jenis ini cenderung berpikir dalam atau dengan gambar dan cenderung mudah belajar melalui sajian-sajian visual seperti film, gambar, video, dan peragaan yang menggunakan model dan slaid. Mereka gemar menggambar, melukis atau mengukir gagasan-gagasan yang ada di kepala dan sering menyajikan suasana serta perasaan hatinya melalui seni.(Jasmine, 2012, pp. 21-22)

Anak-anak dengan kecerdasan visual-spasial yang tinggi cenderung berpikir secara visual. Mereka kaya dengan khayalan internal, sehingga cenderung imajinatif dan kreatif.(Sholeh, 2016, p. 27) Allah mengisyaratkan potensi kecerdasan visual spasial manusia dalam Q.S Hud ayat 37.

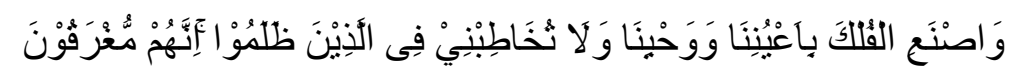

Artinya; Dan buatlah kapal itu dengan pengawasan dan petunjuk wahyu Kami, dan janganlah engkau bicarakan dengan Aku tentang orang-orang yang zalim. Sesungguhnya mereka itu akan ditenggelamkan."

Nabi Nuh As diberikan kecerdasan visual-spasial berupa kemampuannya menerjemahkan wahyu yang diperolehnya untuk membuat bahtera (perahu) menyerupai dada burung. Instruksi yang diwahyukan oleh Allah swt dijalankan dengan baik seperti tergambarkan dalam potongan ayat selanjutnya dalam surah Hud ayat 38 .

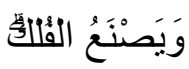

Artinya; Dan mulailah dia (Nuh) membuat kapal....(Kementerian Agama, 2014, p. 226)

Kini tiba tahap selanjutnya, yakni Dan mulailah dia, yakni Nabi Nuh as., membuat dengan sangat mahir-karena ia membuatnya di bawah pengawasan Allah—satu bahtera, yakni perahu besar (Shihab, 2006, p. 626).

\section{Kecerdasan Kinestetik}

Kecerdasan badani-kinestetik sering disebut sebagai kecerdasan kinestetik saja. Orang yang memiliki kecerdasan jenis ini memproses informasi melalui sensasi yang dirasakan pada badan mereka. Mereka lebih nyaman 
38 | Tarbawi : Jurnal Pendidikan Islam Vol. 17. No. 2. Juli - Desember 2020

mengomunikasikan informasi dengan peragaan (demontrasi) atau pemodelan.(Jasmine, 2012, p. 25)

Al Quran mengemukakan satu contoh bagaimana manusia belajar dengan meniru perilaku binatang, yakni saat Qabil membunuh Habil, di mana ia tidak tahu apa yang harus dilakukannya pada mayat saudaranya iu. Allah kemudian mengirim seekor burung gagak yang menggali tanah untuk menguburkan gagal lainnya yang sudah mati. Dari burung gagak itulah Qabil belajar cara menguburkan mayat adiknya.(Najati, 2010, p. 144)

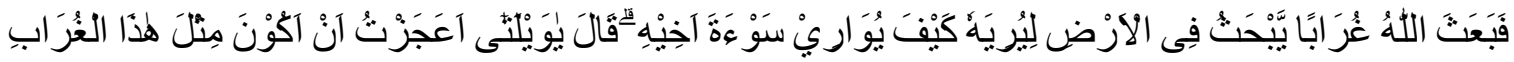

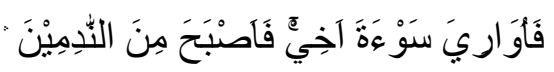

Artinya; Kemudian Allah mengutus seekor burung gagak menggali tanah untuk diperlihatkan kepadanya (Qabil). Bagaimana dia seharusnya menguburkan mayat saudaranya. Qabil berkata, "Oh, celaka aku! Mengapa aku tidak mampu berbuat seperti burung gagak ini, sehingga aku dapat menguburkan mayat saudaraku ini?" Maka jadilah dia termasuk orang yang menyesal.(Kementerian Agama, 2014, p. 112)

Ayat ini mengisyaratkan bahwa cukup lama si pembunuh bingung dan tidak mengetahui apa yang harus dilakukannya. Ini dipahami bukan saja dari kata sau'at/keburukan yang dijelaskan di atas dalam arti bau busuk dan kerusakan badan saudaranya, tetapi juga dari ucapannya setelah melihat burung gagak menggali-gali tanah.

Sementara riwayat mengatakan bahwa burung gagak menggali lubang untuk menguburkan burung gagak yang dibunuhnya. Di sisi lain, dapat juga dikatakan bahwa burung gagak salah satu burung yang terbiasa menggali lubang untuk menanam sebagian dari makanan yang diperolehnya untuk digunakan ada kesempatan lain atau boleh jadi ia menggali tanah untuk mendapatkan sesuatu yang dapat dimakan.

Apapun tujuan burung gagak menggali, apakah menanam gagak yang mati atau makanan atau mencari sesuatu yang pernah disembunyikannya atau tersembunyi di dalam tanah, yang jelas bahwa upayanya menggali itu telah mengilhami Qabil untuk menanam atau menguburkan saudaranya yang terbunuh karena ia mengetahui cara penguburan setelah melihat gagak yang menggali (Shihab, 2002b, pp. 97-98). 
Karena manusia memiliki tabiat meniru, maka memberikan keteladanan adalah faktor penting dalam pendidikan dan pengajaran. Ini dibuktikan oleh Rasulullah saw, yang mana beliau memberikan keteladanan kepada para sahabatnya. Dari Rasulullah itu para sahabat belajar tata cara melaksanakan ibadah. Misalnya, mereka melihat cara Rasululkah berwudhu, shalat, dan berhaji. Para sahabat pun melakukannya dengan cara meniru Rasulullah (Najati, 2010, p. 144).

\section{Kecerdasan Irama-Musik}

Kecerdasan musikal berkaitan dengan kemampuan menangkap bunyibunyi, membedakan, menggubah, dan mengekspresikan diri melalui bunyi-bunyi atau suara yang bernada dan berirama.(Sholeh, 2016, p. 28) Dalam Islam kemampuan dalam kecerdasan musikal dapat ditemui ketika seseorang melantunkan ayat suci al Quran dengan memperhatikan pelafalan makharijul huruf maupun nada dan irama.

Al Quran adalah tanda kebenaran Islam yang terbesar dan mukjizat Rasul yang terhebat. Al Quran dipandang sebagai suatu mikjizat keindahan di samping sebagai mukjizat intelektual, al Quran dapat melumpuhkan keahlian bangsa Arab dengan keindahan pengungkapannya, keindahan susunan dan gaya bahasa, keistimewaan irama dan melodinya, sehingga ada yang menyebutnya sihir. Ahliahli retorika dan sastrawan Arab dari Abdul Qahir hingga Al-Rafi'i, Sayyid Quthb, Bintus Syath'i, dan lainnya pada masa kini telah menjelaskan alasannya tentang keindahan bahsaa al Quran yang dapat melumpuhkan keahlian sastrawan Arab tempo dulu. Dalam membaca al Quran, kita pun dituntut memiliki keindahan suara dan sekaligus memenuhi keindahan ungkapan dan susunan (Yusuf, 2006, p. 262).

Rasulullah SAW bersabda yang diriwayatkan oleh Hakim “Hiasilah al Qur'an dengan suara-suara kalian yang bagus. Sesungguhnya suara yang bagus itu akan menambah keindahan alQur'an."(Muhammad Ibn Abdullah Al Ham Al Naysaburi, 1990 , p. 768) Hadis tersebut menunjukan bahwa kemampuan yang dimiliki manusia berupa suara bagus dengan pengaturan irama yang sesuai akan mampu menambah keindahan al Quran dan kenyamanan bagi para pendengarnya.

\section{Kecerdasan Interpersonal}

Kecerdasan interpersonal ditampakan pada kegembiraan berteman dan kesenangan dalam berbagai macam aktivitas sosial serta ketaknyamanan atau keengganan dalam kesendirian dan menyendiri (Jasmine, 2012, p. 26). 
Kecerdasan antar pribadi (interpersonal) dibangun antara lain atas kemampuan inti untuk mengenali perbedaan; secara khusus, perbedaan besar dalam suasana hati, temperamen, motivasi, dan kehendak. Dalam bentuk yang lebih maju, kecerdasan ini memungkinkan orang dewasa yang mempunyai keterampilan membaca kehendak dan keinginan orang lain, bahkan ketika keinginan itu disembunyikan (Gardner, 2003, p. 45). Al Quran mengisyaratkan kecerdasan interpersonal yang dimiliki manusia dalam Q.S Al-Hujarat ayat 13.

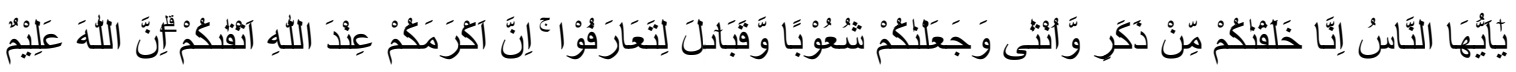

Artinya: Wahai manusia! Sungguh, Kami telah menciptakan kamu dari seorang laki-laki dan seorang perempuan, kemudian Kami jadikan kamu berbangsa-bangsa dan bersuku-suku agar kamu saling mengenal. Sesungguhnya yang paling mulia di antara kamu di sisi Allah ialah orang yang paling bertakwa. Sungguh, Allah Maha Mengetahui, Mahateliti.(Kementerian Agama, 2014, p. 517)

Kata ta'arafu terambil dari kata 'arafa yang berarti mengenal. Patron kata yang digunakan ayat ini mengandung makna timbal balik, dengan demikian ia berarti saling mengenal. Semakin kuat pengenalan satu pihak kepada selainnya, semakin terbuka peluang untuk saling memberi manfaat. Karena itu ayat di atas menekankan perlunya saling mengenal. Perkenalan itu dibutuhkan untuk saling menarik pelajaran dan pengalamn pihak lain, guna meningkatkan ketakwaan kepada Allah swt. Yang dampaknya tercermin pada kedamaian dan kesejahteraan hidup duniawi dan kebahagiaan ukhrawi. Anda tidak dapat menarik pelajaran, tidak dapat saling melengkapi dan menarik manfaat bahkan tidak dapat bekerja sama tanpa saling kenal-mengenal. Saling mengnal yang digarisbawahi oleh ayat di atas adalah "pancing"nya bukan "ikan"nya. Yang ditekankan adalah caranya bukan manfaatnya, karena seperti kata orang, memberi "pancing" jauh lebih baik dari pada memberi "ikan".(Shihab, 2005b, p. 262)

\section{Kecerdasan Intrapersonal}

Kecerdasan intrapersonal adalah kecerdasan mengenai diri sendiri. Kecerdasan ini adalah kemampuan untuk memahami diri sendiri dan bertanggung jawab atas kehidupannya sendiri.(Lwin, 2008, p. 233) Dalam Q.S Ad-Dzariyat ayat 21 


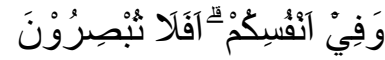

Artinya : dan (juga) pada dirimu sendiri. Maka apakah kamu tidak memperhatikan?(Kementerian Agama, 2014, p. 521)

Dengan bentuk pertanyaan, Allah swt memotivasi manusia agar selalu berusaha mengetahui, mengenali dirinya. Begitu penting dan sentralnya pribadi, AlQurthubi menyebutkan bahwa seluruh pendapat yang disebutkan di atas itulah yang dimaksud dengan mengambil pelajaran (i'tibar), bahwa semua yang ada di tubuh manusia (yang dapat disebut dengan alam kecil) pasti ada padanannya di alam besar (yaitu alam semesta), dan kami juga telah menyebutkan pelajaran apa saja yang dapat diambil dari itu semua, mudah-mudahan mencukupi bagi orangorang yang ingin mentadaburinya (Al-Qurthubi, 2009, p. 249).

\section{Kecerdasan Naturalis}

Inteligensi ini lebih terwujud dalam kemampua mengenal dunia alamiah, alam raya meliputi tanaman, binatang, alam, lingkungan, dan studi saintifik tentang hal itu.(Suparno, 2004, p. 77) Anak-anak dengan kecerdasan naturalis yang menonjol memiliki keterkaitan yang besar terhadap alam sekitar, termasuk pada binatang, di usia yang sangat dini. Mereka menikmati benda-benda dan cerita yang berkaitan dengan fenomena alam, misalnya terjadinya awan dan hujan, asal usul binatang, pertumbuhan tanaman, dan tata surya.(Sholeh, 2016, p. 31)

Isyarat al Quran tentang kecerdasan lingkungan sangat mengagumkan. Dalam perspektif al Quran, orang yang dikatakan memiliki kecerdasan naturalis bukan hanya mengantar manusia untuk memperhatikan, meneliti, memahami, dan mencintai alam raya, akan tetapi kecerdasan ini dapat membawa manusia menyadari bahwa ada Tuhan Yang Mencipta dan Mengatur segala yang ada di alam raya dengan keselarasan yang sempurna. Dengan pemahaman ini, kecerdasan naturalis bukan hanya membawa manusia pada interaksi harmonis dengan alam berdasarkan kesadaran dan pengukuran ketauhidan, akan tetapi juga sebagai bentuk interaksi harmonis dalam bingkai ibadah kepada Allah swt.

Dengan bentuk pengejewantahan ibadah kepada Allah, seseorang dengan kecerdasan naturalis dipastikan tidak akan melakukan suatu tindakan yang menyimpang/ dilarang oleh ajaran agama, baik dalam interaksinya dengan lingkungan, apalagi terhadap Tuhan dan manusia. Ini karena orang yang memiliki kecerdasan lingkungan akan menyadari kesatuan dan relasi mutual antara Tuhan, 
alam dan manusia. Pengertian ini tentu sangat berbeda dengan kecerdasan naturalis dalam versi Gardner seperti yang diungkap di atas, yang hanya menekankan pemahaman dan kemampuan berinteraksi harmonis dengan lingkungan. Pengertian ini masih sangat kering dari nilai spiritual.(Zuhdi, 2015, pp. 775-776) Pengertian kecerdasan naturalis dalam al Qur'an dapat dipahami di antaranya dari isyarat al Qur'an berikut ini:

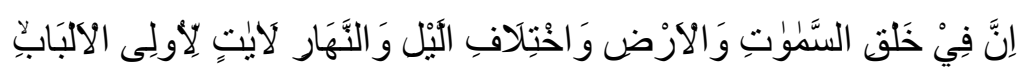

Artinya : Sesungguhnya dalam penciptaan langit dan bumi, dan pergantian malam dan siang terdapat tanda-tanda (kebesaran Allah) bagi orang yang berakal,(Kementerian Agama, 2014, p. 75)

Kata al-albab adalah bentuk jamak dari lubb yaitu seperti sesuatu. Kacang, misalnya memiliki kulit yang menutupi isinya. Isi kacang dinamai lubb. Ulul Albab adalah orang-orang yang memiliki akal yang murni, yang tidak diselubungi oleh "kulit", yakni kabut ide, yang dapat melahirkan kerancuan dalam berpikir. Yang merenungkan tentang fenomena alam raya akan dapat sampai kepada bukti yang sangat nyata tentang keesaan dan kekuasaan Allah swt.(Shihab, 2007, p. 307)

Lebih lanjut dijelaskan dalam surah Ali Imran ayat 191 terkait dengan term Ulul Albab

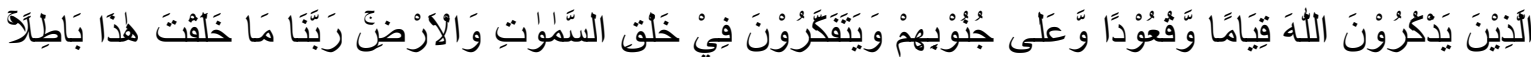

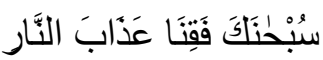

Artinya: (yaitu) orang-orang yang mengingat Allah sambil berdiri, duduk atau dalam keadaan berbaring, dan mereka memikirkan tentang penciptaan langit dan bumi (seraya berkata), "Ya Tuhan kami, tidaklah Engkau menciptakan semua ini sia-sia; Mahasuci Engkau, lindungilah kami dari azab neraka.(Kementerian Agama, 2014, p. 75)

Di atas terlihat bahwa objek zikir adalah Allah, sedang objek pikir adalah makhluk Allah berupa fenomena alam. Ini berarti pengenalan kepada Allah lebih banyak didasarkan kepada kalbu, sedang pengenalan alam raya oleh penggunaan akal, yakni berpikir. Akal memiliki kebebasan seluas-luasnya untuk memikirkan fenomena alam (Shihab, 2007, p. 309).

Ini adalah cara al Quran yang luar biasa cerdas dalam merangkum kesimpulan besar tentang sifat orang yang dikatakan memiliki kecerdasan naturalis, yaitu orang yang memiliki sikap tanggungjawab sebagai seorang individu, makhluk sosial dan spiritual. Kecerdasan naturalis dalam Islam, membuat manusia 
menyadari seutuhnya bahwa, manusia adalah aktor penanggungjawab dalam mengelola alam raya, boleh mengambil manfaatnya, tetapi tetap harus memelihara dan menjaga kelestariannya (Zuhdi, 2015, pp. 776-777).

\section{Kecerdasan Eksistensial}

Kecerdasan eksistensial berkiatan dengan kemampuan seseorang untuk menempatkan diri dalam lingkup kosmos yang terjauh, dengan makna hidup, makna kematian, nasib dunia jasmani maupun kejiwaan, dan dengan makna pengalaman mendalam seperti cinta atau kesenian.(Sholeh, 2016, p. 31) Inteligensi ini lebih menekankan orang untuk bertanya akan kediriannya, keberadaannya di dunia ini (Suparno, 2004, p. 78).

Anak yang memiliki kecerdasan eksistensial (1) cenderung memiliki kesadaran akan hakaikat sesuatu; (2) menanyakan berbagai hal yang mungkin sekali tidak terpikirkan oleh anak lain sebayanya.(Sholeh, 2016, p. 31) Hal ini tergambarkan dalam Q.S Adz-Dzariyat ayat 56.

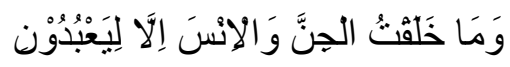

Artinya: Aku tidak menciptakan jin dan manusia melainkan agar mereka beribadah kepada-Ku.

Nash yang singkat ini mengandung hakaikat yang besar dan mencengangkan. la merupakan salah satu hakaikat semesta terbesar. Sebab, kehidupan manusia di bumi takan stabil tanpa meyakini dan memahami hakaikat ini, baik dalam kehidupannya sebagai individu maupun masyarakat dan sebagai umat manusia secara keseluruhan dengan peran dan zaman yang bervariasi. Nash itu menyingkap berbagai sisi dan sudut konseptual dan tujuan, yang semuanya tercakup oleh hakikat yang besar ini, yang dianggap sebagai batu fondasi di mana kehidupan berdiri. Sisi pertama dari hakikat ini ialah bahwa di sana terdapat tujuan tertentu dari keberadaan jin dan manusia,yang tercermin pada tugas. Barangsiapa yang melaksanakan dan menunaikan tugas itu, berarti dia telah merealisasikan tujuan keberadaannya.(Qutb, 2004, p. 49)

Intinya Allah SWT memberikan anugerah kepada manusia bermacammacam kecerdasan tujuannya adalah untuk mengagungkan zat Allah dan manjadikan manusia menjadi hamba yang pandai bersyukur atas kemampuan yang dimiliki. Kemampuan yang dimiliki manusia hendaknya juga dapat memberikan manfaat bagi makhluk ciptaan Allah SWT yang lain. 
Hal yang membedakan konsep multiple intelligences yang dikenal selama ini dengan konsep multiple intelligences perspektif al Quran/ Hadits adalah belum adanya nilai-nilai spiritual yang muncul dalam setiap kecerdasan. Nilai-nilai spiritual selalu muncul dalam setiap kecerdasan majemuk (multiple intelligences) yang terdapat di al Quran/ Hadits. Nilai-nilai tersebut seperti, setiap kecerdasan yang dimiliki manusia merupakan pemberian Allah SWT yang seharusnya dikembangkan, setiap kecerdasan yang dimiliki manusia hendaknya dijadikan sarana untuk memberi manfaat bagi makhluk ciptaan Allah lainnya, kecerdasan yang diberikan Allah SWT menjadi jalan hamba untuk lebih bersyukur atas segala nikmat yang ada.

\section{B. Implikasi Konsep Multiple Intelligences Perspektif AI Quran/ Hadis terhadap Pembelajaran Pendidikan Agama Islam}

Dilihat dari keberadaannya dalam kurikulum pendidikan nasional, pendidikan agama Islam (PAI) merupakan salah satu dari tiga mata pelajaran yang harus dimasukan dalam kurikulum setiap lembaga pendidikan formal di Indonesia. Hal ini karena hidup beragama merupakan salah satu dimensi kehidupan yang sangat penting pada setiap individu dan warga negara. Melalui pendidikan agama diharapkan mampu terwujud individu-individu yang berkepribadian utuh sejalan dengan pandangan hidup bangsa.

Untuk itu, pendidikan agama Islam memiliki tugas yang sangat berat, yakni bukan hanya mencetak peserta didik pada satu bentuk, tetapi berupaya untuk menumbuhkembangkan potensi yang ada pada diri mereka seoptimal mungkin serta mengarahkannya agar pengembangan potensi tersebut berjalan sesuai dengan nilainilai ajaran Islam.

Dengan demikian, mengingat berat dan besarnya peran pendidikan agama Islam, maka perlu diformulasikan sedemikian rupa, baik yang menyangkut sarana insani maupun non insani secara komprehensif dan integral. Formulasi yang demikian bisa dilakukan melalui sistem pengajaran agama Islam yang baik dengan didukung oleh sumber daya manusia (guru) yang berkualitas, metode pengajaran yang tepat, dan sarana prasarana yang memadai.(Nasih and Kholidah, 2009, p. 6)

Siswa pada hakaikatnya telah dianugerahi potensi awal yang harus dikembangkan sedemikian rupa oleh guru dengan beragam strategi dan metode pembelajaran sesuai kecerdasan masing-masing siswa. Siswa tidak boleh lagi 
ipandang layaknya seperti gelas kosong yang siap diisi dengan tuangan materi oleh guru, tetapi pada dasarnya siswa sudah memiliki pengetahuan awal yang siap dikembangkan. Ini sesuai dengan konsep pembelajaran kontekstual

Pendekatan pembelajaran kontekstual merupakan rancangan pembelajaran yang dibangun atas dasar asumsi bahwa knowledge is constructed by human. Atas dasar itu, maka dikembangkan pendekatan pembelajaran kontruktivis yang membuka peluang seluas-luasnya kepada siswa untuk memberdayakan diri. Cara belajar yang terbaik adalah siswa yang mengkontruksi sendiri secara aktif pemahamannya.(Zayadi and Majid, 2005, pp. 10-11)

Pembelajaran kontekstual bertujuan untuk membekali siswa dengan pengetahuan yang fleksibel dapat diserap/ ditransfer dari satu permasalahan ke permasalahan lain dan dari satu konteks ke konteks yang lainnya. Pembelajaran kontekstual dapat dikatakan sebagai sebuah pendekatan pembelajaran yang mengakui dan menunjukan kondisi alamiah dari pengetahuan. Melalui hubungan di dalam dan di luar kelas, suatu pendekatan pembelajaran konteksual menjadi pengalaman lebih relevan dan berarti bagi siswa dalam membangun pengetahuan yang akan mereka terapkan dalam pembelajaran seumur hidup.(Zayadi and Majid, 2005, p. 12)

Kecerdasan majemuk (multiple intelligences) dan pembelajaran kontekstual erat kaitannya ketika masuk dalam sebuah proses pembelajaran.Guru kecerdasan majemuk memiliki banyak pilihan strategi dan metode pembelajaran ketika menyampaikan materi dan mampu mengaitkan materi tersebut dalam kehidupan nyata yang dialami siswa di lingkungannya.

Contoh Implementasi Multiple Intelligences dalam Pembelajaran PAI

Satuan Pendidikan : MTs

Semester : : Gasal

Kelas : VIII

Materi : Fiqh

Topik/ Sub Topik : Zakat Fitrah

Langkah-langkah :

1. Siswa mendengarkan penyampaian guru mengenai hakaikat zakat sebagai bentuk penghambaan kepada Allah SWT (kecerdasan linguistik dan eksistensial) 
46 | Tarbawi : Jurnal Pendidikan Islam Vol. 17. No. 2. Juli - Desember 2020

2. Siswa menghitung besaran zakat yang harus dikeluarkan umat muslim Indonesia apabila menggunakan uang (1 kg beras: Rp. 12.000) (kecerdasan logis-matematis)

3. Siswa memperhatikan tayangan slide mengenai golongan yang berhak menerima zakat fitrah (kecerdasan visual-spasial)

4. Siswa secara berkelompok berkeliling lingkungan sekolah mencari orang-orang yang wajib mengeluarkan zakat dan yang termasuk ke dalam delapan golongan yang berhak menerima zakat (kecerdasan kinestetik, interpersonal dan logis-matematis)

5. Siswa diperintahkan untuk menanyakan perasaan golongan yang wajib mengeluarkan zakat dan golongan yang berhak menerima zakat melalui tulisan dan ungkapan yang indah (kecerdasan intrapersonal dan linguistik)

6. Guru memotivasi siswa untuk selalu berempati kepada orang yang membutuhkan melalui zakat (kecerdasan interpersonal)

7. Siswa membuat gambar pemandangan alam yang gersang dan alam yang subur sebagai perumpamaan jika di dunia ini banyak orang menunaikan zakat dan tidak menunaikan zakat (kecerdasan visual spasial dan natural)

8. Penutup, siswa diajak menyanyikan lagu "zakat" (kecerdasan musikal)

Dengan model pembelajaran seperti ini, masing-masing kecerdasan yang dimiliki para siswa dapat terfasilitasi secara keseluruhan, sehingga dampaknya mampu menghilangkan kejenuhan karena aktivitasnya bervariasi. Poin penting disini adanya pengakuan baik langsung maupun tidak langusng terhadap kemampuan yang dimiliki siswa tanpa ada pengeualian. Hal ini akan menimbulkan minat dan motivasi tinggi siswa terhadap proses pembelajaran.

\section{SIMPULAN}

Allah SWT mengisyaratkan kemampuan manusia terkait dengan ranah kecerdasan bahasa dalam surah al-Baqarah ayat 31-33. Ayat tersebut menunjukan proses pengajaran bahasa yang dilakukan Allah SWT kepada Nabi Adam AS sampai kepada bukti yang ditunjukan Adam untuk menyebutkan nama-nama yang diperintahkan Allah. Kecerdasan logis-matematis tertuang dalam surah al-Ankabut ayat 43. Ayat tersebut mengisyaratkan bahwa hanya orang yang berilmu yang dapat memahami perumpamaan-perumpamaan yang dibuat oleh Allah SWT. Kecerdasan visual-spasial yang dimiliki manusia ditunjukan Allah SWT dalam surah Hud ayat 37- 
38. Ayat ini menunjukan kemampuan Nabi Nuh AS ketika bersama kaumnya yang beriman diminta untuk membuat perahu besar untuk mengarungi banjir yang akan datang. Al Qur'an mengabadikan peristiwa pembunuhan Qabil terhadap Habil ini sekaligus menunjukan kecerdasan kinestetik yang dimiliki manusia dalam surah alMaidah ayat 31. Ayat ini menunjukan bagaimana burung gagak mampu mengilhami Qabil dengan memperlihatkan cara menguburkan mayat burung gagak yang telah mati. Allah menganugerahi manusia dengan kecerdasan irama-musik agar dipergunakan untuk melantunkan ayat-ayat suci al Quran yang memiliki keindahan susunan dan gaya bahasanya. Manusia diciptakan berbangsa-bangsa dan bersukusuku. Itulah redaksi dalam surah al-Hujarat ayat 13 yang menunjukan hakaikat manusia sebagai manusia yang diciptakan berbeda antara satu dengan lainnya. Perbedaan yang ada harus menjadi sarana untuk saling mengenal antara pribadi yang satu dengan pribadi yang lain. Allah mengisyaratkan dalam surah ad-Dzariyat ayat 21 mengenai kecerdasan intrapersonal yang dimiliki untuk senantiasa tafakur guna memperoleh kesadaran akan kemampuan yang dimiliki dan ha-hal apa yang tersimpan dalam dirinya. Orang yang memiliki kecerdasan naturalis bukan hanya dibekali kemampuan meneliti, memperhatikan, dan mencintai alam raya tetapi ia akan sadar akan adanya pencipta alam raya sehingga sampai kepada rasa syukur atas semua pemberian-Nya. Isyarat al Qur'an berkaitan dengan kecerdasan naturalis terdapat dalam surah Ali Imran ayat 190-191. Allah mengisyaratkan kecerdasan eksistensial yang dimiliki manusia dalam surah ad-Dzariyat ayat 56. Ayat tersebut menyebutkan bahwa manusia pada hakikatnya diciptakan hanya untuk beribadah kepada Allah SWT. Menurut Sayyid Quthb hidup manusia takan stabil tanpa mampu memahami hakikat kehidupannya baik sebagai individu maupun makhluk sosial.

Multiple Intelligences sangat diperlukan dalam model pembelajaran dewasa ini. Guru sangat dimudahkan apabila mampu melihat kecerdasan yang dimiliki setiap siswa. Materi disampaikan dengan strategi pembelajaran yang dapat memfasilitasi setiap kecerdasan yang dilmiliki siswa. Melalui strategi tersebut siswa memiliki motivasi tinggi dikarenakan proses pembelajaran lebih variatif. Poin penting disini adanya pengakuan baik secara langsung maupun tidak langsung terhadap kemampuan yang dimiliki siswa tanpa pengecualian.

\section{DAFTAR PUSTAKA}

Al-Maragi, A.M., 1986. Tafsir Al-Maragi. Toha Putra, Semarang. 
Al-Qurthubi, S.I., 2009. Tafsir Al-Qurthubi. Pustaka Azzam, Jakarta.

Azwar, S., 1996. Pengantar Psikologi Intelegensi. Pustaka Pelajar, Yogyakarta.

Chatib, M., 2016. Orangtuanya manusia: melejitkan potensi dan kecerdasan dengan menghargai fitrah setiap anak. Bandung: Kaifa.

Chatib, M., Said, A., 2012. Sekolah Anak-anak Juara: Berbasis Kecerdasan Jamak dan Pendidikan Berkeadilan. Kaifa, Bandung.

Departemen Agama RI, 2004. Pedoman Pendidikan Agama Islam di Sekolah Umum. Depag-RI, Jakarta.

Gardner, H., 2003. Multiple Intelligences. Interaksara, Tangerang.

Jasmine, J., 2012. Metode Mengajar Multiple Intelligences. Nuansa Cendekia, Bandung.

Kementerian Agama, 2014. Al-Quran, Tajwid, dan Terjemah. Diponegoro, Bandung.

Lajnah Pentashihan Mushaf Al-Qur'an, 2010. Pendidikan, Pembangunan Karakter, Dan Pengembangan Sumber Daya Manusia. Lajnah Pentashihan Mushaf Al-Qur'an, Jakarta.

Lwin, M., 2008. Cara Mengambangkan Berbagai Komponen Kecerdasan. Indeks, Jakarta.

Majid, A., Andayani, D., 2004. Pendidikan agama Islam berbasis kompetensi: konsep dan implementasi kurikulum 2004. Remaja Rosdakarya, Bandung.

Muhammad Ibn Abdullah Al Ham Al Naysaburi, I.A.A., 1990. al Mustadrak ala al Sahihayn. Dar al "ilmiyah, Beirut.

Najati, M.U., 2010. Psikologi Qur'ani: Dari Jiwa Hingga IImu Laduni. Marja, Bandung.

Nasih, A.M., Kholidah, L.N., 2009. Metode dan Teknik Pembelajaran Pendidikan Agama Islam. Refika Aditama, Bandung.

Pasiak, T., 2002. Revolusi IQ/EQ/SQ: Menyingkap Rahasia Kecerdasan Berdasarkan AIQur'an dan Neurosains Mutakhir. Mizan, Bandung.

Qutb, S., 2004. Fi Zhilalil Qur'an. Gema Insani, Jakarta.

Relvan, E., 2005. Pendekatan Multi Kecerdasan Menurut Gardner dan Implikasinya Bagi Pembelajaran Pendidikan Agama Islam. Fakultas IImu Tarbiyah dan Keguruan UIN Sunan Kalijaga Yogyakarta, Yogyakarta.

Shihab, M.Q., 2007. Tafsir Al-Misbah: Pesan, Kesan, dan Keserasian AlQur'an. Lentera Hati, Jakarta. 
Shihab, M.Q., 2006. Tafsir Al-Misbah: Pesan, Kesan, dan Keserasian AlQur'an. Lentera Hati, Jakarta.

Shihab, M.Q., 2005a. Tafsir Al-Misbah: Pesan, Kesan dan Keserasian alQur'an. Lentera Hati, Jakarta.

Shihab, M.Q., 2005b. Tafsir Al-Misbah: Pesan, Kesan, Dan Keserasian AlQur'an. Lentera Hati, Jakarta.

Shihab, M.Q., 2002a. Tafsir Al-Misbah: Pesan, Kesan, dan Keserasian alQuran. Lentera Hati, Jakarta.

Shihab, M.Q., 2002b. Tafsir Al-Misbah: Pesan, Kesan, dan Keserasian AlQur'an. Lentera Hati, Jakarta.

Shihab, M.Q., 1996. Wawasan Alquran. Mizan, Bandung.

Sholeh, K., 2016. Kecerdasan Majemuk: Berorientasi Pada Partisipasi Peserta Didik. Pustaka Pelajar, Yogyakarta.

Suparno, P., 2004. Teori Intelgensi Ganda dan Aplikasinya di Sekolah. Kanisius, Yogyakarta.

Yaumi, M., Ibrahim, N., 2013. Pembelajaran Berbasis Kecerdasan Jamak. Kencana Prenadamedia Group, Jakarta.

Yuliani Nurani, S., Bambang, S., 2010. Bermain kreatif berbasis kecerdasan jamak. Jakarta: Indeks.

Yusuf, A.A., 2006. Islam dan Sains Modern. Pustaka Setia, Bandung.

Zayadi, A., Majid, A., 2005. Tadzkirah: Pembelajaran Pendidikan Agama Islam (PAI) Berdasarkan Pendekatan Kontekstua. RajaGrafindo Persada, Jakarta.

Zuhdi, M.H., 2015. Fiqh Al-Bi'ah: Tawaran Hukum Islam dalam Mengatasi Krisis Ekologi. Al-'Adalah 12, 771-784. 
50 | Tarbawi : Jurnal Pendidikan Islam Vol. 17. No. 2. Juli - Desember 2020

Konsep Multiple Intelligences Perspektif Al-Quran/ Hadis dan Implikasinya Terhadap Pembelajaran Pendidikan Agama 